Unesco board set to agree compromise on bioethics committee

[PARIS] Uncertainty over the future of the International Bioethics Committee (IBC) of the United Nations Educational Scientific and Cultural Organization (Unesco) is likely to be resolved at a meeting of the UN agency's 58-member executive board this week.

The IBC was set up in 1994 with the task of drafting the first UN text governing science and human rights, the "universal declaration on the human genome and human rights". But that remit ended with the adoption of the declaration last November by the 186 member states of Unesco.

At the same time, the declaration gave the IBC the new role of overseeing the implementation of the text's provisions, a set of broad principles affirming the need to protect the individual against genetic discrimination while upholding the principle of scientific freedom.

Member states have now rejected a Unesco proposal that the IBC, which is made up of independent experts appointed by Unesco director-general Federico Mayor, be replaced with a committee of both experts and civil servants from member states.

Under a compromise to be submitted to the executive board, the $36-$ member IBC will remain independent, while a separate committee representing member states will be set up in parallel. But how this arrangement will work in practice is far from obvious.

One new activity for the IBC, for example, will be to release 'opinions' on ethical issues. But it is not clear whether the IBC will be able to make these public immediately, or whether they will first have to be approved by the second committee.

In negotiations this month, the compromise proposal won broad agreement, with support, for example, from France, the United Kingdom, Japan and Israel - as well as the United States, which is not a member of Unesco. Germany favoured a political committee, however, apparently on the grounds that this would allow greater control.

Meanwhile, Unesco's executive committee will also be asked to approve a proposal to create a separate World Commission on the Ethics of Scientific Knowledge and Technology, which would consider ethical issues in areas outside biomedicine. The commission would be chaired by Vigdis Finnbogadottir, a former president of Iceland.

Under preliminary proposals, the commission's goal would be to promote debate among scientists, intellectuals, public and private decision-makers, and the public on the ethical and risk issues in such areas as energy, the use of freshwater resources and the information society.

Declan Butler

\title{
Free market is advocated for Australian universities
}

[CANBERRA] Radical recommendations in the final report of a review of financing and policy for higher education in Australia have set the scene for a heated debate on university policy in the run-up to the next general election, due within 11 months.

A seven-member panel chaired by Roderick West, a retired head teacher of a private school, is advocating opening the 37 universities completely to market forces through deregulation and tuition fees.

The report contains no financial analysis of the impact of its proposals - an omission that has drawn widespread criticism. But there is stronger coverage of research issues, given little attention in a draft released last November (see Nature390, 212; 1997).

Teaching and research are more specifically linked, and the final report stresses the need for "strategic planning, priority setting and greater coordination of national research effort", in contrast to the 'market' philosophy it applies elsewhere.

The main recommendation for students is that they should receive 'entitlements' from the government at standard levels set for three broad grades of courses (basic, laboratory-based, clinically based) which they could 'cash' at the university of their choice. Universities would compete for enrolments, and widely differing fees are expected.

This would replace the system under which universities receive grants according to government-approved numbers of students, which are supplemented by partial fees paid by students after they graduate.

In addition, universities could capitalize their assets (which would be audited) and then sell or borrow against them. But they would liable for taxation like businesses.

Asked how a deregulated system would address the crisis said to be facing science in universities, the West committee said that science enrolments have been increasing and expressed confidence that "the market" would sort out any short-term problems.

Vice-chancellors reacted cautiously, but John White, policy secretary for the Australia Academy of Science, says that, although West "perceptively diagnoses serious structural and financial problems within the system", the remedy "is narrow in its philosophical base and even paradoxical". Academic and student bodies criticized the report as "regressive and irresponsible".

The committee says its goal is to turn Australia into "a lifelong learning society" through a new financing and regulatory framework to cope with increased expectations for higher education. It is confident that information technology will "revolu- tionize" management and what it calls the "education products" of universities.

Speaking at the report launch on 17 April, West declared faith in the ability of students to select courses and universities, and to have "a real say in what universities provide". If adopted, he said, the committee's scheme would "avoid negotiation between govern-

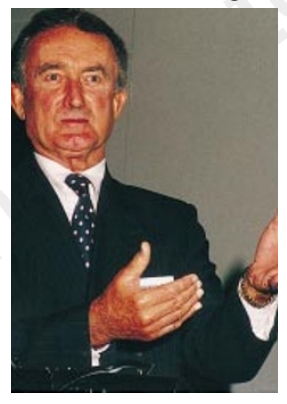

West: wants students to drive funding. ment and universities as students drive public funding and Canberra bureaucrats are taken out of the equation".

Noting that "current funding levels are causing tension", the review's scheme is based on no overall increase in public support. But it still believes government should maintain, over five years, the average of public funding per equivalent full-time undergraduate student.

In a rare quoting of figures, the committee says that, on current trends, the level of overhead support for project grants will decline from 28 cents in the dollar (the US figure exceeds 50 cents) to 12 cents by 2000 , and could only be maintained with an additional A \$13 million (US\$8.5 million) in 1999 and $A \$ 55$ million a year from 2000 . It says an increase is "warranted".

The most significant reform in research would see the Australian Research Council established as "an independent body" with "a wider range of functions and increased accountability and transparency”. Currently part of the Education Department, the ARC would be responsible for setting national university research policy after being given "explicit authority to determine priorities within its own programmes".

But the review's advocacy of nationally directed priorities in funding for university research contrasts with support for a "student centred" approach to funding research training, where places would be competitive.

The review's prospects of gaining government support for its key proposals have been placed in serious doubt by the education minister, David Kemp, who repeated his earlier rejection of 'vouchers' for students and 'deregulated fees' for universities.

Kemp's first major speech on universities has declared his own agenda for reform, indicating that he is likely to take note only of those of West's recommendations that fit his preferences, such as linking student choice with funding mechanisms.
PeterPockley 